\title{
FRACTIONATION OF PROTEASES FROM COWTAIL RAY (Trygon sephen) VISCERA USING POLYACRYLIC ACIDS
}

\author{
Achmad Poernomo*)
}

\begin{abstract}
Fractionation of proteases of cowtail ray (Trygon sephen) viscera using polyacrylic acids has been investigated. The viscera were ensiled using a mixture of propionic and formic acids $(1: 1, \mathrm{v} / \mathrm{v})$ at a level of $3 \%(\mathrm{v} / \mathrm{w})$ at $40^{\circ} \mathrm{C}$ for 5 days. Fractionation was carried out step wise at $4^{\circ} \mathrm{C}$ to produce highest possible activity of the enzymes at respective fractions. It was shown that an addition of $2 \%$ polyacrylic acids (PAA) solution to produce $0.275 \%$ PAA in the final solution followed by $\mathrm{pH}$ adjustment to $\mathrm{pH} 4.0$ of fraction containing acidic protease, and to $\mathrm{pH}$ 8.0 of that containing alkaline protease has been able to sep arate alkaline and acidic proteases. The process also purified the enzymes by 1.1 and 4.7 fold for acidic and alkaline proteases. respectively.
\end{abstract}

KEYWORDS: cowtail ray, ensilation, fractionation, polyacrylic acids, proteases

\section{INTRODUCTION}

Many methods have been studied and applied to separate proteins in solution from one another, and precipitation using polyelectrolytes is a method that is frequently used for such purpose. This technique is considered fast and safe especially to maintain the biological activity of proteins such as enzymes.

Charged polymers have been used by several workers to precipitate proteins from solution, and at the same time fractionate protein from other proteins or compounds. This method has been reported able to separate amyloglucosidase from transglucosidase (Sternberg, 1972; 1975), lipoxygenase from b-amylases (Sternberg, 1976), alkaline from acidic proteases of salmon viscera (Reece, 1988), lysozyme from egg white (Fischer \& Glatz, 1988), as well as in precipitating trypsin from a pepsin-trypsin mixture (Sternberg \& Hershberger, 1973), plant proteases (Caygill et al., 1983), chitosanase (Boucher et al., 1992) and lysozyme (Sternberg \& Hershberger, 1973; Fischer \& Glatz, 1988; Shieh, 1989). The charged polymers commonly used are carboxymethyl cellulose, methacrylate polymers, polyethyleneimine (PEI) and polyacrylic acids (PAA).

Cowtail ray (T. sephen) viscera contain several different enzymes, some of which belong to proteases group. Ensilation has proved able to extract the enzymes (Poernomo, 1998), and separation of individual enzymes is necessary since it will assist the purification of the enzymes, especially if the enzymes have different characteristics, such as those from fish viscera. This paper deals with the fractionation of alkaline and acidic proteases of cowtail ray viscera silage using PAA solution to facilitate subsequent purification and characterisation of the enzymes.

\section{MATERIALS AND METHODS}

Cowtail ray (T. sephen) viscera were obtained from fish drying processors at Labuhan Maringgai, Lampung, Sumatera. Separation and washing of viscera were carried out at the process. ing sites. The viscera were road transported in ice $(1: 1, w / w)$ to the laboratory of the Slipi Research Station for Marine Fisheries, Jakarta which took about 8-10h. Upon arrival, the viscera were once more washed in fresh water, frozen and stored at $-45^{\circ} \mathrm{C}$ until used.

Enzymes extraction was conducted by ensilation of the viscera. Chopped (ca. $1 \times 1 \mathrm{~cm}$ ) viscera was added with a mixture of propionic and formic acids $(1: 1, \mathrm{v} / \mathrm{v})$ at a level of $3 \%(\mathrm{v} / \mathrm{w})$, and kept at $40^{\circ} \mathrm{C}$ for 5 days during which the mixture was stirred daily. The silage was then centrifuged at $10,000 \mathrm{xg}$ for $10 \mathrm{~min}$. The sediment was separated from the silage, while the lipid on the surface was skimmed off. The supernatant was frozen $\left(-45^{\circ} \mathrm{C}\right)$ in a chest freezer overnight and was stored at $-25^{\circ}$ to $-30^{\circ} \mathrm{C}$ until used.

Before used, the silage supernatant was thawed in running water and centrifuged $(10,000 \mathrm{xg}, 10$ $\min )$ at $4^{\circ} \mathrm{C}$ and then added with $1 / 3$ volume of ice-

\footnotetext{
*) Researcher of the Central Research Institute for Fisheries, Jakarta
} 


\section{A. Poernomo}

cold chloroform to remove the remaining fat. Afterward, the mixture was left at $4^{\circ} \mathrm{C}$, for $15 \mathrm{~min}$, then the lower layer was separated using a separating funnel and finally recentrifuged to remove the remaining chloroform and fat. After centrifugation, the lower layer was separated and referred to as crude enzyme extracts.

The alkaline and acidic proteases were fractionated with PAA solution (MW 3-5 million Dalton/MD, Carbopol C934, BF-Goodrich) through a series of preliminary trials at $4^{\circ} \mathrm{C}$. A volume of crude enzyme extract was mixed with $2 \%(\mathrm{w} / \mathrm{v})$ PAA solution to produce various concentrations $(0.0125$ to $0.3 \%)$ of PAA in the final mixture. The mixtures were stirred for $30 \mathrm{~min}$ and then centrifuged $(10,000 \times g, 10 \mathrm{~min})$. The supernatant $\left(\mathrm{S}_{1}\right)$ was separated and referred to as acidic protease extracts.

The precipitates were redissolved in $0.4 \mathrm{M}$ Tris buffer $\mathrm{pH} 8.5$ with an addition of $1 \mathrm{M} \mathrm{CaCl}_{2}$ to produce $50 \mathrm{mM}$ in the final mixture. The mixture was stirred for $10 \mathrm{~min}$ and recentrifuged. The subsequent supernatant $\left(S_{2}\right)$ was separated and referred to as alkaline protease extracts.

The PAA concentration producing the highest acidic protease activity and lowest alkaline protease activity in $S_{1}$ and lowest acidic protease activity and highest alkaline protease activity in $S_{2}$ was applied in the next trial. In the second trial, $S_{1}$ was adjusted to $\mathrm{pH} 4.0, \mathrm{pH} 3.5$ and $\mathrm{pH} 3.0$, while $\mathrm{S}_{2}$ was adjusted to $\mathrm{pH} 8.5$ and $\mathrm{pH} 9.0$ using $2 \mathrm{~N}$ $\mathrm{HCl}$ or $2 \mathrm{~N} \mathrm{NaOH}$, respectively. Schematically, the process is illustrated in Figure 1.

Protease activity was monitored by the method of Barret (1972) modified by Martinez et al. (1988). Universal buffers of pH 3 and 8 (Johnson \& Lindsey 1939) were used as assay buffers and for enzyme dilution. Alkaline protease was monitored at $\mathrm{pH} 8$ using $8 \%$ casein in $50 \mathrm{mM} \mathrm{Na()H}$, while acidic protease was monitored at $\mathrm{pH} 3$ using $8 \%$ hemoglobin in deionised water.

To a mixture of $0.5 \mathrm{~mL}$ assay buffer and 0.25 $\mathrm{mL}$ substrate equilibrated at $25^{\circ} \mathrm{C}$ was added 0.25

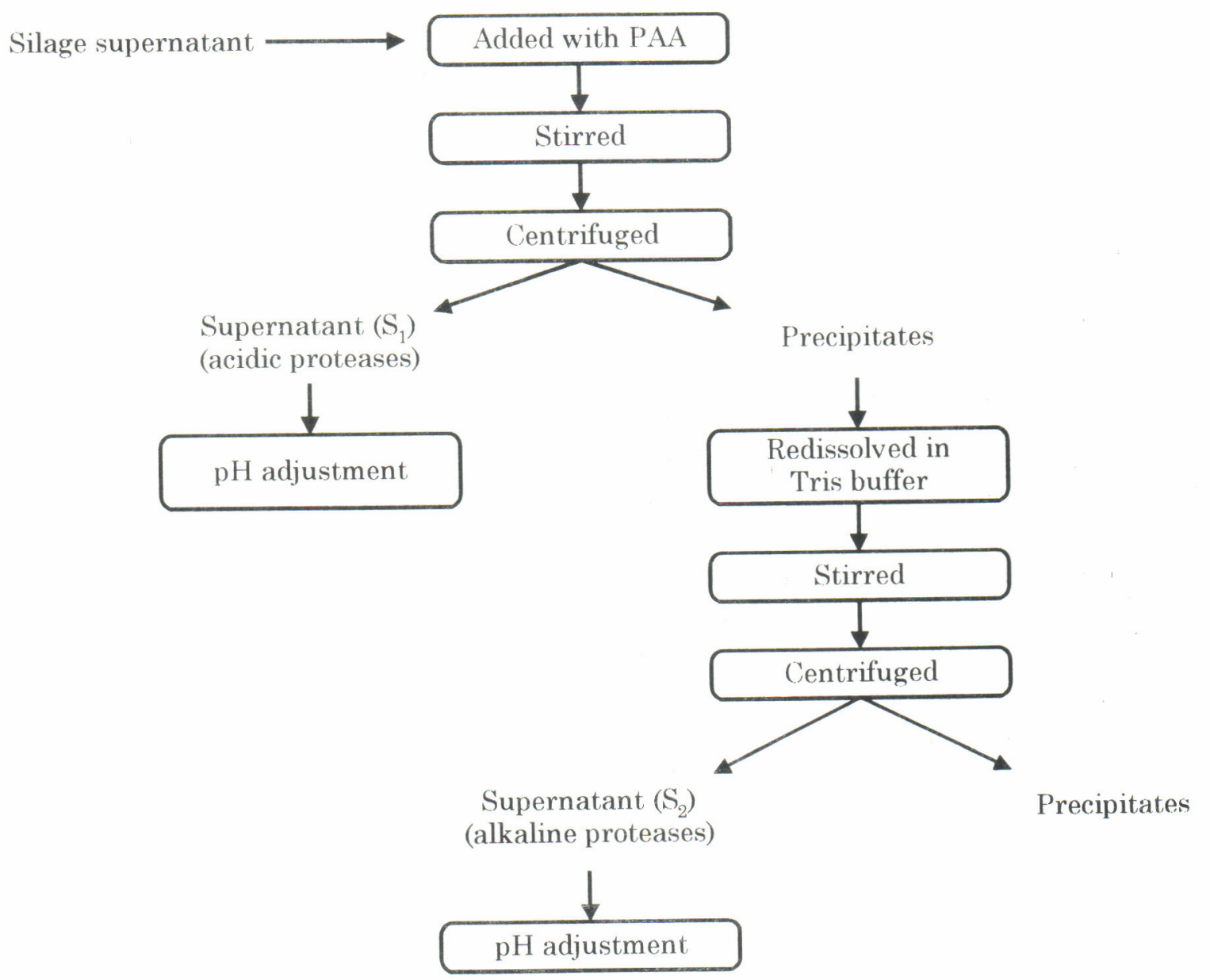

Figure 1. Fractionation of alkaline and acidic proteases using polyacrylic acids (PAA). 
$\mathrm{mL}$ enzyme solution. After $60 \mathrm{~min}$ incubation at $25^{\circ} \mathrm{C}, 5 \mathrm{~mL} 6 \%$ TCA was added to stop the reaction. Filtration was done after 15 min using Advantec filter paper no. 131 (equivalent to Whatman filter paper no. 3). The absorbance of the filtrate was read at $280 \mathrm{~nm}$ and was corrected for the respective blanks. Blanks were obtained in a similar manner, but TCA was added before the enzyme. One unit of enzyme activity was defined as the increase of absorbance by 1.0 at $280 \mathrm{~nm}$ of $\mathrm{TCA}$ soluble material in $60 \mathrm{~min}$ at $25^{\circ} \mathrm{C}$.

\section{RESULTS}

The results of fractionation of alkaline and acidic proteases are presented in Figure 2 and Table 1. In the first trial (Figure 2), acidic proteases always remained in $S_{1}$ at levels of more than about $80 \%$ of the original and precipitated (contained in $\mathrm{S}_{2}$ ) at levels lower than 5\%. Alkaline proteases, however, remained in $\mathrm{S}_{1}$ at levels higher than those in the precipitate (in $S_{2}$ ) for PAA final concentrations below $0.1 \%$. At final concentrations higher than $0.1 \%$, the alkaline protease activities were higher in the precipitate (in $S_{2}$ ) than in $S_{1}$.

A PAA final concentration of $0.2 \%$ resulted in the highest acidic protease activity in $S_{1}$ (about $98 \%$ ). However, at this concentration, the supernatant still contained about $30 \%$ alkaline protease activity, while in $\mathrm{S}_{2}$, the alkaline protease activity was still low (about 50\%) although the acidic protease activity was also low (about 3\%). At a PAA final concentration of $0.275 \%$, highest alkaline protease activity (about $65 \%$ ) in $\mathrm{S}_{2}$ was obtained. At this concentration, about $80 \%$ of acidic protease activity was retained in $S_{1}$ while the alkaline protease activity in $S_{1}$ was the lowest. This treatment was used in the subsequent fractionation step.

The $\mathrm{pH}$ adjustment of $\mathrm{S}_{1}$ and $\mathrm{S}_{2}$ was to inactivate the alkaline protease in $S_{1}$ and acidic protease

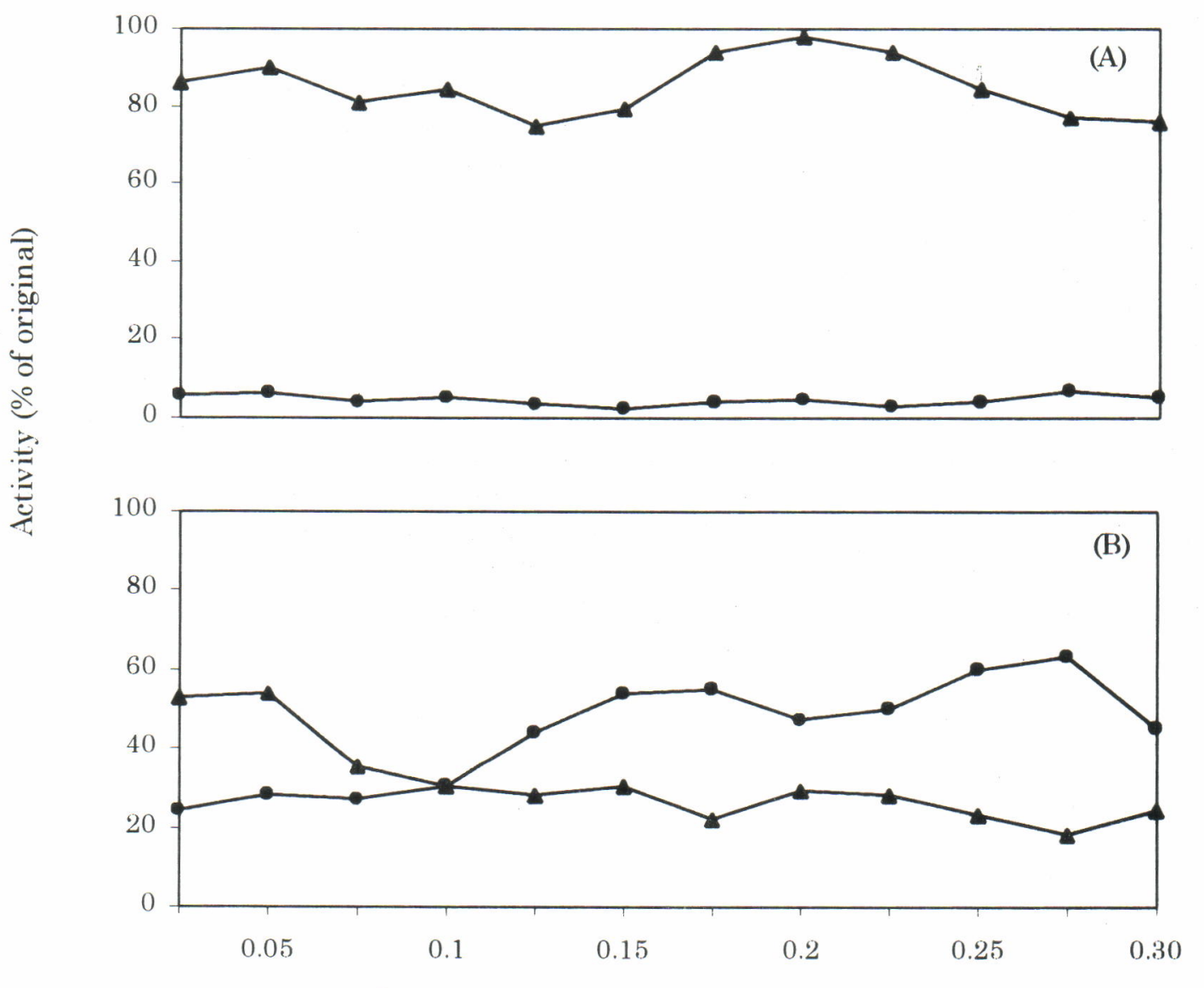

PAA concentration $(\%, w / v)$ in final mixture

Figure 2. Distribution of acidic and alkaline proteases activity after PAA addition $\mathrm{A}=$ Acidic proteases; $\mathrm{B}=$ Alkaline proteases; $\boldsymbol{\Delta}=$ Supernatant $\left(\mathrm{S}_{1}\right) ; \boldsymbol{-}$ Precipitate $\left(\mathrm{S}_{2}\right)$ 
Table 1. Distribution (\%) of acidic and alkaline proteases during fractionation with PAA and $\mathrm{pH}$ adjustment

\begin{tabular}{lcccc}
\hline \multirow{2}{*}{$\begin{array}{c}\text { Fractionation } \\
\text { step }\end{array}$} & \multicolumn{2}{c}{ Supernatant $\left.\mathbf{( S}_{\mathbf{1}}\right)$} & \multicolumn{2}{c}{ Precipitate $\left(\mathbf{S}_{2}\right)$} \\
\cline { 2 - 5 } & $\begin{array}{c}\text { Acidic } \\
\text { activity* }\end{array}$ & $\begin{array}{c}\text { Alkaline } \\
\text { activity* }\end{array}$ & $\begin{array}{c}\text { Acidic } \\
\text { activity* }\end{array}$ & $\begin{array}{c}\text { Alkaline } \\
\text { activity * }\end{array}$ \\
\hline PAA ** & $77.9 \pm 3.8$ & $6.1 \pm 0.3$ & $19.8 \pm 0.2$ & $60.8 \pm 2.0$ \\
pH adjustment:*** & - & - & & \\
9.0 & - & - & 0 & $57.4 \pm 1.9$ \\
8.5 & $99.5 \pm 2.0$ & 0 & - & $63.1 \pm 1.4$ \\
4.0 & $76.0 \pm 1.7$ & 0 & - & - \\
3.5 & $12.1 \pm 0.7$ & 0 & - & - \\
3.0 & & 0 & - & - \\
\hline
\end{tabular}

\footnotetext{
* \% of original, values are means \pm standard deviation for 2 replicates, each from 3 determinations.

1 enzyme unit was defined as the increase of the absorbance at $280 \mathrm{~nm}$ of TCA soluble material in $60 \mathrm{~min}$ at $25^{\circ} \mathrm{C}$ using casein or hemoglobin as substrate

** Final concentration is 0.275

$* * *$ IJsing $2 \mathrm{~N} \mathrm{HCl}$ or $\mathrm{NaOH}$
}

in $\mathrm{S}_{2}$. As shown in Table 1, the $\mathrm{pH}$ adjustment of $\mathrm{S}_{2}$ did not significantly change the alkaline protease activity. However, the acidic protease activity of this fraction was eliminated. The alkaline protease activity in $\mathrm{S}_{2}$ was zero after $\mathrm{pH}$ adjustment, but the acidic protease activity declined as the $\mathrm{pH}$ was reduced to $3.5(76 \%$ remained) and 3.0 (12.1\% remained). At $\mathrm{pH} 4.0$, the acidic protease activity increased to $99.5 \%$ of the original.

Fractionation also partly purified the enzymes, and in a separate study it was shown that fractionation steps such as those in this study have been able to purify the enzymes by 1.1 and 4.7 fold for acidic and alkaline proteases, respectively (Table 2)

\section{DISCUSSION}

The specific activity of alkaline protease in the supernatant of cowtail ray viscera silage, as shown in Table 1, was lower than that of salmon viscera silage as reported by Reece (1988). This was probably due to the differences in species as well as the procedure of ensilation. Moreover, cowtail ray is an elasmobranch fish which does not have a distinct pyloric caeca as a source of alkaline proteases. The period of silage storage in the present study was 5 days at $40^{\circ} \mathrm{C}$ and this might have affected the stability of alkaline protease in acidic conditions. Reece (1988) further reported that alkaline proteases of cod and mackerel viscera were not stable under acidic conditions during ensilation and only acidic proteases were recovered.

In the present study, PAA was used since it has been used by Sternberg \& Hershberger (1973). Caygill et al. (1983) and Reece (1988) to successfully fractionate alkaline and acidic proteases. In addition, in the preliminary study, the use of another polyelectrolyte, PEI, to precipitate acidic proteases proved unsatisfactory. In the precipitation of protein by PEI, salt must be added to aid the process (Bell et al., 1983: Jendrisak, 1987) and salt was found to affect enzyme activity (Thongthai et al., 1990; Gildberg, 1993; (Gildberg et al., 1991; Xu et al., 1996).

The use of low molecular weight (90,000D) PAA was also tested in the preliminary study. However. the results were not satisfactory since the contamination of acidic proteases was high in the precipitate. Although low molecular weight (90,000-250,000D) PAA has been successful in precipitating some enzymes (Sternberg \& Hershberger, 1973; Sternberg, 1976; Shieh \& (Glatz, 1991; Boucher et al., 1992), it seems that low molecular weight PAA was not suitable for fractionation of alkaline and acidic proteases from cowtail ray viscera. In the fractionation of transglucosidase and amyloglucosidase (Sternberg, 1975) PAA of at least 1MD molecular weight was recommended. According to Sternberg (1976) the formation of an insoluble proteinpolyacrylate complex depends among others on the molecular weight of PAA and the ratio of $\mathrm{PAA} /$ 
IFR Journal Vol. V No.1, 1999

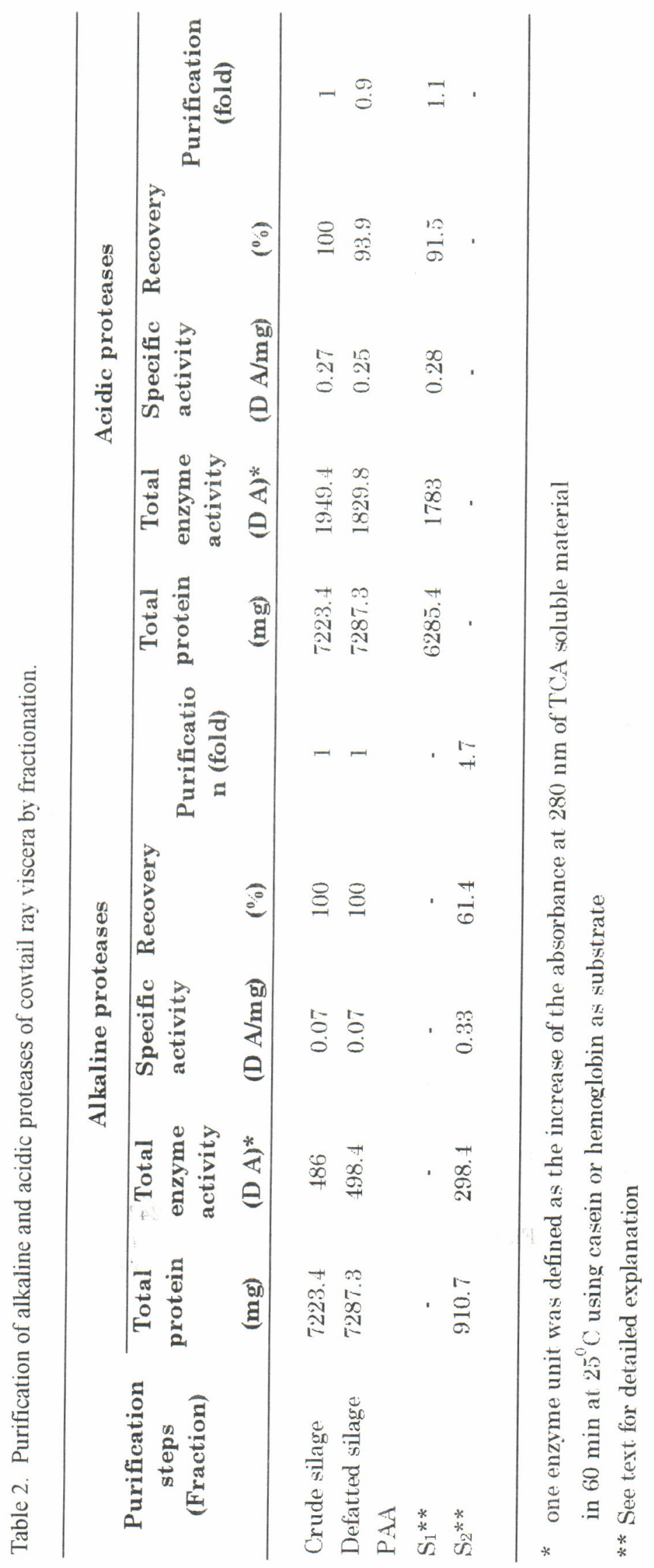




\section{A. Poernomo}

protein. Higher molecular weight PAA was then tested in the present study.

Using PAA of 3-5MD molecular weight, the precipitation pattern of the alkaline protease. which was indicated by the enzyme activities, was asymmetrically bell shaped (Figure 2). A similar result was also shown by (aygill et al. (1983) for plant proteases (papain and ficin) and Boucher et al. (1992) in precipitating Streptomyces N174 chitosanase. It was suggested that the decrease in recovery at higher polyelectrolyte dosage was due to the excess polyelectrolyte which was incorporated into the already formed protein-polyelectrolyte complex, resulting in a soluble complex with a significant net charge, and thus hindering the aggregation of the complexes (Caygill et al., 1983; Clark \& Glatz, 1987, 1988; Chen \& Berg, 199:3).

In their studies. (aygill et al. (1983) employed PAA/protein ratios of 0.02-0.5, while Boucher et al. (1992) used ratios of up to 10 . The optimum ratio for plant proteases was between 0.14-0.29 and 0.2-0.4 for papain and ficin, respectively. while for chitosanase it was around 4 . In the present study, with final concentration of PAA in the mixture ranging from 0.025 to $0.3 \%$, or a PAA/ protein ratio of 0.006 to 0.075 the optimum ratio to achieve the highest alkaline protease activity in the precipitate was 0.069 . These ratios were much lower than those of the above studies which could be due to the different natures of the proteases as well as the PAA. Boucher et al. (1992) used PAA with molecular weight of 250,000I), while the one used in the present study was :3$5 \mathrm{MD}$. The molecular weight of PAA used by Caygill et al. (198:3) was not reported.

A similar ratio of PAA/protein (0.066) was used by Reece (1988) to separate alkaline protease from acidic protease of salmon viscera silage. No investigation of the optimum ratio was reported in Reece's study. However, it was reported that the alkaline protease activity in the precipitate was $82.7 \%$ of the original, while that of acidic proteases in the supernatant was $100 \%$. The data for the acidic protease in Reece's study were reported to be modified to take into account of the co-purification of the alkaline protease, however, no explanation of the modifications were mentioned. No data on the activity of alkaline protease in the supernatant or acidic protease in the precipitates were reported. PAA precipitation in Reece's study increased the purity of the acidic and alkaline proteases by 1.6 and 6.8 fold, respectively, while in the present study, activities were 1.1 and 4.7 fold, respectively.

\section{CONCLUSION AND RECOMMENDATION}

This study showed that polyacrylic acids were able to fractionate proteases from cowtail ray viscera and at the same time increased the purity of the enzymes. It was demonstrated that the optimum fractionation condition was an addition of $2 \%(w / v)$ PAA to produce $0.275 \%$ in the final mixture, followed by $\mathrm{pH}$ adjustment of supernatant containing acidic protease to $\mathrm{pH} 4.0$. and of that containing alkaline protease to $\mathrm{pH}$ 8.5. This treatment increased the specific activity of alkaline and acidic proteases by 4.7 and 1.1 fold, respect. ively. Practical protocol on the fractionation is necessary to be developed so that the procedure can be applied in higher scale of fractionation. Further purification following fractionation needs to be investigated so that the enzymes can be properly characterized.

\section{REFERENCES}

Barret. A.J. 1972. Lysosomal enzymes. In. I)ingle. J.T. (ed.). Lysosomes: A Laboratory Handbook. North-Holland Publ. ('o., Amsterdam. p. 46-1:35.

Bell, D..J., Hoare, M. and Dunnil, P. 198:. The formation of protein precipitates and their centrifugal recovery. In Fiechter, A. (ed.). Dounstream Processing. Adv. Biochem. Eng./Biotechnol. 26: 172.

Boucher, I.. D)upuy, A., Vidal, P., Neugebauer. W.A. and Brzezinski, R. 1992. Purification and characterization of chitosanase from Streptomyces N174. Appl. Microbiol. Biotechnol. 38(2): 188-193.

Caygill, J.C., Moore, I).J. and Kanagasbapathy. L. 1983. Concentration of plant proteases by precipitation with polyacrylic acids. Enzyme Microbiol. Technol. 5: 365-368.

Chen. W. and Berg, I.C. 1993. The effect of polyelectrolyte dosage on floc formation in protein precipitation by polyelectrolyte. Chem. Eng. Sici. 48 (10): $1775-1784$.

Clark, K.M. and Crlatz, C.E. 1987. Polymer dosage considerations in polyelectrolyte precipitation of protein. Biotechnol. Prog. 3 (4): 241-247.

Fischer, R.R. and Clatz, C.E. 1988. Polyelectrolyte precipitation of proteins: I. The effect of reactor conditions. Biotechnol. Bioeng. 32: 777-785.

Gildberg, A. (1993) Enzymic processing of marine raw materials. Process Biochem. 28: 1-15.

Gildberg, A., Olsen, R.L. and Bjarnason, J.B. (1991) Characteristics and composition of pepsins from Atlantic cod. In D) unn, B.M. (ed.). Structure and Function of the Aspartic Proteinases: Genetics, Structures and Mechanisms. New York: Plenum Press; 107-110

Jendrisak, J. 1987. The use of polyethyleneimine in protein purification. In Burgess, R. (ed.). Protein Purification: Micro to Macro. New York: Alan R. Liss. Inc. p. 75-97. 
Johnson. W.C. and Lindsey, A.J. 1939. An improved universal buffer. Analyst. (Lond.) 64: 490-492.

Martinez, A., Olsen, R.L. and Serra, J.L. 1988. Purification and characterisation of two trypsinlike enzymes from the digestive tract of anchovy (Engraulis encrasicholus). Comp. Biochem. Physiol. $91 \mathrm{~B}(4): 677-684$.

Poernomo, A. 1998. The extraction and activity of crude enzymes from Cowtail Ray (T. sephen) viscera. Indones. Fish. Res. J. IV(1): 39-45.

Reece, P. 1988 . Recovery of proteases from fish waste. Process Biochem. 23 (3): 62-66.

Shieh, J.Y. 1989. Role of Polyelectrolyte Molecular Weight in Protein Recovery by Polyelectrolyte Precipitation. MSc Thesis. Iowa State University, Ames, Iowa. 95 pp.

Shieh, J.Y. and Glatz, C.E. 1991. Precipitation of proteins with polyelectrolytes: Roles of polymer molecular weight and modification of protein charge. Polymer Preprints 32 (1): 606-607.

Sternberg, M. 1972. Purification of amyloglucosidases. Chem. Abstr. 77: $112490 f$.
Sternberg, M. 1975. Removal of Transglucosidase from Amyloglucosidase. US Patent No. 3,917,513.

Sternberg, M. 1976. Purification of industrial enzymes with polyacrylic acids. Process Biochem. Sept. p. 11.12.

Stenberg, M. and Hershberger, D. 1973. Separation of proteins with polyacrylic acids. Biochem. Biophys. Acta 342: 195-206.

Thongthai, C., Panbangred, W., Khoprasert, C. and Dhaveetiyanond (1990) Protease activities in the traditional process of fish sauce fermentation. In Reilly, P.J.A., Parry, R.W.H. and Barile, L.E. (Eds.). Post-harvest technology, preservation and quality of fish in Southeast Asia. Proceedings of the Workshop on Post-harvest Technology, Preservation and Quality of Fish in Southeast Asia. Bangkok, Thailand, November 13-17, 1989. Stockholm: International Foundation for Science. p. 61-65.

Xu, R.A., Wong, R.J., Rogers, M.L. and Fletcher, (..C. (1996) Purification and characterisation of acidic proteases from the stomach of the deepwater finfish orange roughy (Hoplostethus atlanticus). J. Food Biochem. 20: 31-48. 
